\title{
Novel Initiating System for the Stereocontrolled Radical Polymerization of Acrylamides: Alkyl Bromide/Rare Earth Metal Triflate System
}

\author{
Biswajit Ray, Yutaka Isobe, Shigeki Habaue, ${ }^{*}$ Masami Kamigaito, and Yoshio Oкамото ${ }^{\dagger}$ \\ Department of Applied Chemistry, Graduate School of Engineering, Nagoya University, \\ Furo-cho, Chikusa-ku, Nagoya 464-8603, Japan \\ ${ }^{*}$ Department of Chemistry and Chemical Engineering, Faculty of Engineering, Yamagata University, \\ 4-3-16 Jonan, Yonezawa 992-8510, Japan
}

(Received February 27, 2004; Accepted June 5, 2004; Published September 15, 2004)

\begin{abstract}
A novel radical initiating system - rare-earth metal triflate $\left[\mathrm{Y}(\mathrm{OTf})_{3}, \mathrm{Yb}(\mathrm{OTf})_{3}, \mathrm{Lu}(\mathrm{OTf})_{3}\right.$, $\left.\mathrm{Sc}(\mathrm{OTf})_{3}\right]$ and alkyl halide containing $\alpha$-esters (ethyl 2-bromoisobutyrate and ethyl 2-bromopropionate) or $\alpha$-amide ( $N, N$-dimethyl-2-bromo-2-methylpropanamide) was used for the stereocontrolled radical polymerization of $N$-isopropylacrylamide (NIPAM). The Lewis acids serve a dual role as the promoter of the radical initiation and the controller of the stereospecific polymerization. The effects of the Lewis acid type and concentration, the initiator type and concentration, solvents, and temperature on the polymerization of NIPAM have been reported. The chain-end structure of the resulting polymer was determined by ${ }^{1} \mathrm{H}$ NMR. We also extended this initiating system for the polymerization of $N, N$-dimethylacrylamide, styrene, $n$-butyl acrylate, and methyl methacrylate. [DOI 10.1295/polymj.36.728]

KEY WORDS Rare-Earth Metal Triflates / $\alpha$-Haloesters / $\alpha$-Haloamide / $N$-Isopropylacrylamide / Stereocontrolled Radical Polymerization /
\end{abstract}

Radical polymerizations are usually initiated by azo compounds, peroxides, or redox initators with the iron ion. ${ }^{1}$ Recent progresses in controlled radical polymerization $^{2-5}$ have widened the scope of the radical initiators, one of which should be an initiating system consisting of an alkyl halide and a late transition metal complex of ruthenium, iron, copper, etc. ${ }^{3}$ In this system, the initiating radical is born from the alkyl halide due to the metal-mediated cleavage of the carbon-halogen bond. The organic halide is thus regarded as an initiator, which generates an initiating radical species, while the metal complex as a catalyst, which mediates the radical formation via the reversible one-electron redox reaction of the metal center. This transitionmetal catalyzed radical polymerization system originates from a similar metal-catalyzed radical addition reaction as already reported. ${ }^{6}$

An alternative way for the generation of the radical species from an alkyl halide is to use a free radical initiator like AIBN and $\mathrm{Et}_{3} \mathrm{~B} / \mathrm{O}_{2}$ together for the halogen abstraction. ${ }^{6}$ This combination is often employed for the organic synthesis of small and sometimes cyclic compounds in atom-transfer free radical addition. ${ }^{6}$ Recent progress in this area concerns the addition of a Lewis acid such as metal triflates $\left[\mathrm{M}(\mathrm{OTf})_{n}, \mathrm{M}=\mathrm{Sc}, \mathrm{Yb}\right.$, etc. $]$ into the addition reaction between an $\alpha$-halo ester, nitrile, or amide and an olefin in the presence of $\mathrm{Et}_{3} \mathrm{~B} / \mathrm{O}_{2}$, where the added
Lewis acid improves the reactivity of the slow atomtransfer reaction. ${ }^{7-12}$ The improvement stems from the weakening of the $\mathrm{C}-\mathrm{Br}$ bond due to the coordination of the Lewis acid to the carbonyl or the nitrile group of the $\alpha$-halo ester, nitrile, or amide compounds. ${ }^{12-14}$ This results in an increase in both the rate of the addition of the $\alpha$-carbonyl radical to the olefin and also the halogen abstraction by the resulting nucleophilic carbon radical.

Quite recently, we have found that the metal triflates also dramatically accelerated the radical polymerization of acrylamides and other meth(acrylic) monomers with AIBN. ${ }^{15-22}$ The Lewis acids further affected the stereochemistry of the polymers. Especially, for the acrylamides, highly isotactic polymers were obtained with rare-earth metal triflates. The increase in the rate and the stereoregularity is considered to be due to the coordination of the Lewis acid to the carbonyl groups of the chain ends and the monomer.

Here, we will report a novel initiating system consisting of an $\alpha$-halo ester and a rare-earth metal triflate for the strereocontrolled radical polymerization of acrylamides. This system can be differentiated from the late transition metal-catalyzed one because the radical formation relies on the coordination of the Lewis acid to the carbonyl group adjacent to the carbon-halogen bond, which is subsequently cleaved

${ }^{\dagger}$ To whom correspondence should be addressed (E-mail: okamoto@ apchem.nagoya-u.ac.jp). 


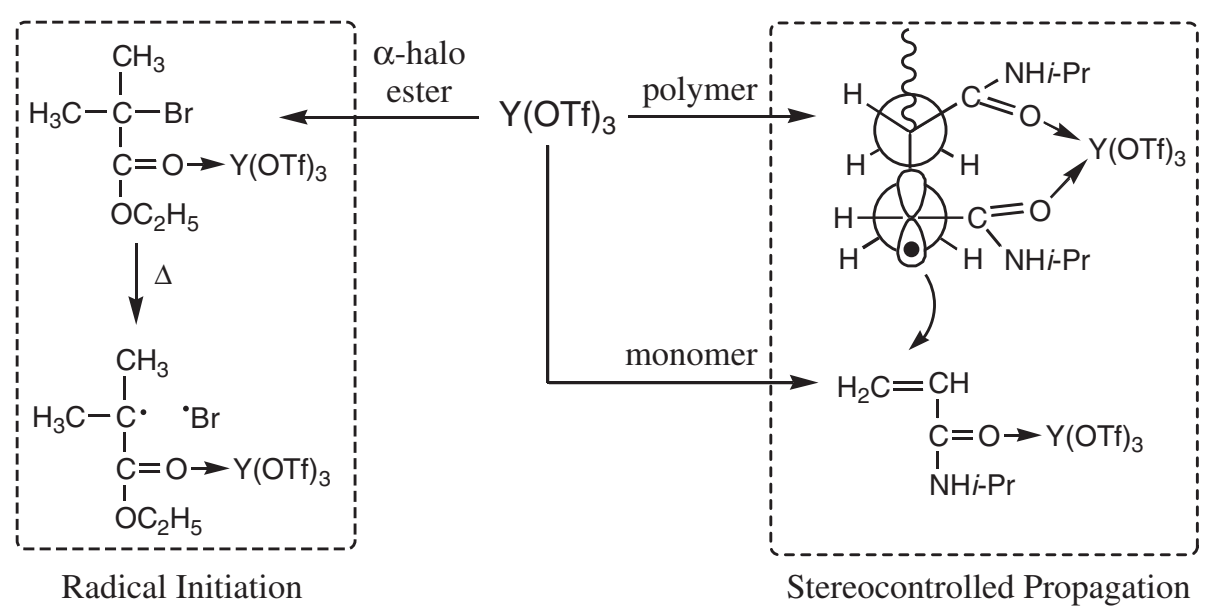

Scheme 1. Dual role of $\mathrm{Y}(\mathrm{OTf})_{3}$ in $\mathrm{R}-\mathrm{Br} / \mathrm{Y}(\mathrm{OTf})_{3}$ initiating system for stereocontrolled radical polymerization of NIPAM.

upon heating to generate the initiating radical species. No added free radical initiators are needed unlike in the reported atom-transfer radical addition. ${ }^{7-12}$ Another role of the Lewis acid in the polymerization is to mediate the stereocontrol during the radical polymerization. The Lewis acid thus plays the dual roles of radical initiation and stereocontrolled propagation. Scheme 1 illustrates the dual roles of $\mathrm{Y}(\mathrm{OTf})_{3}$ in the ethyl 2-bromoisobutyrate (EBIB)/Y(OTf $)_{3}$ system for the stereocontrolled radical polymerization of $\mathrm{N}$ isopropylacrylamide (NIPAM). The effect of the variation in the Lewis acid type and concentration, the initiator type and concentration, solvents, and temperature on the polymerization of NIPAM will be reported here. The chain-end structure of the resulting polymer was examined by ${ }^{1} \mathrm{H}$ NMR. We also extended this initiation system for the polymerization of $\mathrm{N}, \mathrm{N}$-dimethylacrylamide (DMAM), styrene, $n$-butyl acrylate, and methyl methacrylate (MMA).

\section{EXPERIMENTAL}

NIPAM (Wako Pure Chemical Industries, Ltd., $>98 \%$ ) was recrystallized twice from hexane. EBIB (Sigma Aldrich Japan K.K, 98\%) and ethyl 2-bromopropionate (EBP) (Aldrich, 99\%) were distilled over calcium hydride under reduced pressure. $N, N$-dimethyl-2-bromo-2-methylpropanamide (DBMP) was synthesized according to the literature. ${ }^{23} \quad \mathrm{Y}(\mathrm{OTf})_{3}$ (Aldrich, 98\%), $\mathrm{Yb}(\mathrm{OTf})_{3}$ (Aldrich, 99.99\%), and $\mathrm{Sc}(\mathrm{OTf})_{3}$ (Aldrich, 99\%) were dried under vacuum before use. DMAM (Wako, 98\%), styrene (Wako, 99\%), n-butyl acrylate (Wako, 98\%), and MMA (Wako, 98\%) were dried overnight over calcium hydride and distilled over calcium hydride under reduced pressure before use. Dehydrated methanol (Kanto Kagaku, >99.8\%), dehydrated toluene (Kanto, $>99.5 \%$ ), dehydrated tetrahydrofuran (THF) (Kanto,
$>99.5 \%)$ and $N, N$-dimethylformamide

(DMF)

(Kanto, $>99.5 \%$ ) were used as received.

The polymerization was carried out in a dry glass tube capped with a two-way glass stopper under dry nitrogen. For a typical polymerization, the required amounts of NIPAM and $\mathrm{M}(\mathrm{OTf})_{3}(\mathrm{M}=\mathrm{Y}, \mathrm{Yb}, \mathrm{Sc}$, $\mathrm{Lu})$ were placed in a dry glass tube and dried under vacuum for $1 \mathrm{~h}$. For the copolymerization of NIPAM with styrene, styrene was then added using a degassed syringe. For the polymerization of DMAM, styrene, $n$-butyl acrylate, and MMA, each monomer was added using a degassed syringe after drying the desired amount of $\mathrm{M}(\mathrm{OTf})_{3}$ under vacuum for $1 \mathrm{~h}$. The required amounts of the methanol solvent and alkyl halide solution of toluene were then added using degassed syringes. The tube was then placed in a thermostated bath at $80^{\circ} \mathrm{C}$ for a desired time. The reaction was stopped by cooling at $-78^{\circ} \mathrm{C}$. The reaction mixture was precipitated in a large excess of diethyl ether and isolated by centrifugation. The isolated products containing the polymer and $\mathrm{M}(\mathrm{OTf})_{3}$ were dried overnight at $60^{\circ} \mathrm{C}$ under vacuum. The polymer yields were gravimetrically determined from the ether-insoluble crude polymer samples. The polymer was freed from the Lewis acid by dissolving the polymer-Lewis acid mixture in methanol and precipitating it from an excess amount of water at room temperature. This procedure was repeated three times to completely remove the Lewis acid from the polymer.

The average molecular weights and polydispersities of the poly(NIPAM) and poly(DMAM) were measured by size exclusion chromatography (SEC) against polystyrene standards in DMF containing $0.1 \mathrm{~mol} / \mathrm{L}$ $\mathrm{LiCl}$ with a flow rate of $0.5 \mathrm{~mL} / \mathrm{min}$ at $40^{\circ} \mathrm{C}$ on two polystyrene gel columns: TSK gel $\alpha$-M (Bead size: $13 \mu \mathrm{m}$ and measurable molecular weight range: $10^{2.5}-10^{7}$ ) and TSK gel $\alpha-3000$ (Bead size: $7 \mu \mathrm{m}$ and measurable molecular weight range: $10^{2.5}-10^{5}$ ) 
using JASCO RI-930 and JASCO UV-970 detectors. The average molecular weights and polydispersities of the polystyrene, $\operatorname{poly}(n$-butyl acrylate), and poly(MMA) were measured by size exclusion chromatography (SEC) against polystyrene standards in THF with a flow rate of $1 \mathrm{~mL} / \mathrm{min}$ at $40^{\circ} \mathrm{C}$ on two polystyrene gel columns: TSK gel $\mathrm{GMH}_{\mathrm{HR}}-\mathrm{H}$ and TSK gel $\mathrm{G} 3000 \mathrm{H}_{\mathrm{HR}}$ using JASCO RI-930 and JASCO UV970 detectors. The ${ }^{1} \mathrm{H}$ NMR spectra were recorded on a Varian Gemini 2000 spectrometer $(400 \mathrm{MHz})$. The diad tacticities of poly(NIPAM) and poly(DMAM) were determined from the methylene proton peaks of the polymer recorded in DMSO- $d_{6}$ at $170{ }^{\circ} \mathrm{C} .{ }^{15}$ The triad tacticity of poly(MMA) was determined on the basis of the peaks of the $\alpha$-methyl group in the ${ }^{1} \mathrm{H}$ NMR spectrum measured in $\mathrm{CDCl}_{3}$ at room temperature. The composition of the copolymer of styrene-NIPAM was determined from the ${ }^{1} \mathrm{H}$ NMR spectra measured in DMSO- $d_{6}$ at $170^{\circ} \mathrm{C}$.

For the ${ }^{1} \mathrm{H}$ NMR analysis of a mixture of EBIB and $\mathrm{Y}(\mathrm{OTf})_{3}$, the required amount $(0.064 \mathrm{~g})$ of $\mathrm{Y}(\mathrm{OTf})_{3}$ was weighed into a degassed NMR tube inside a glove box and capped with a septum and taken out of the glove box and connected to a vacuum pump for $1 \mathrm{~h}$ in order to dry the Lewis acid. To it and to another septum-capped degassed NMR tube, a $\mathrm{N}_{2}$-purged $2.5 \mathrm{mM}$ EBIB solution $(0.6 \mathrm{~mL})$ in a toluene- $\mathrm{CD}_{3} \mathrm{OD}$ $(1 / 1, v / v)$ mixture was added using a degassed syringe. These two NMR tubes were sealed under $\mathrm{N}_{2}$. The ${ }^{1} \mathrm{H}$ NMR spectra of the two mixtures were checked and put in a thermostated bath at $80^{\circ} \mathrm{C}$ for $24 \mathrm{~h}$. Finally, the ${ }^{1} \mathrm{H}$ NMR spectra of the two mixtures were again checked after heating.

\section{RESULTS AND DISCUSSION}

\section{Polymerization Under Different Conditions}

Table I shows the results of the polymerization of NIPAM under different conditions. NIPAM was not polymerized either in the presence of $\mathrm{Y}(\mathrm{OTf})_{3}$ (entry 1) or EBIB (entry 2) alone at $80^{\circ} \mathrm{C}$. The polymerization did not occur even using both EBIB and $\mathrm{Y}(\mathrm{OTf})_{3}$ at $60^{\circ} \mathrm{C}$ (entry 3 ). However, the polymerization occurred using both EBIB and $\mathrm{Y}(\mathrm{OTf})_{3}$ at $80^{\circ} \mathrm{C}$ (entry 4). The polymer yield reached about $75 \%$ in $13 \mathrm{~h}$. The observed molecular weight $\left(M_{\mathrm{n}}\right)$ and polydispersity of the polymer are $8.89 \times 10^{4}$ and 2.72 , respectively. The tacticity $(m \%)$ of the polymer is 79 . The increase in temperature from $80^{\circ} \mathrm{C}$ to $100^{\circ} \mathrm{C}$ (entries 4 and 5) while keeping the other conditions the same, increases the polymer yield (88\%), but decreases the molecular weight $\left(7.67 \times 10^{4}\right)$ and the polydispersity (2.50) and tacticity $(m=77 \%)$ of the obtained polymers. The polymerizations also took place using EBIB only (entry 6) and EBIB and $\mathrm{Y}(\mathrm{OTf})_{3}$ combined (entry 7 ) under UV irradiation at $30^{\circ} \mathrm{C}$. There was no polymerization using both EBIB and $\mathrm{Y}(\mathrm{OTf})_{3}$ at $80^{\circ} \mathrm{C}$ in the presence of the radical scavenger, 1,1-diphenyl-2-picrylhydrazyl (DPPH) (entry 8). These results indicate that the stereocntrolled radical polymerization of NIPAM occurred in the presence of EBIB and $\mathrm{Y}(\mathrm{OTf})_{3}$.

The effects of $\mathrm{Y}(\mathrm{OTf})_{3}$ on EBIB was studied by measuring the ${ }^{1} \mathrm{H}$ NMR spectra of EBIB in the presence and absence of $\mathrm{Y}(\mathrm{OTf})_{3}$ in toluene/ $\mathrm{CD}_{3} \mathrm{OD}$ $(1 / 1, \mathrm{v} / \mathrm{v})$ at $80^{\circ} \mathrm{C}$. As shown in spectra (i) and (ii) in Figure 1, there was no change in the EBIB absorptions without the Lewis acid after heating at $80^{\circ} \mathrm{C}$ for $24 \mathrm{~h}$. In contrast, the formation of a dimer of EBIB (2,2,3,3-tetramethyl-succinic acid diethyl ester) (NMR yield $=78 \%$ ) was observed, in the presence of $\mathrm{Y}(\mathrm{OTf})_{3}$ (spectra (iii) and (iv) in Figure 1). The product is most probably due to the coupling of the radical species generated by the cleavage of the $\mathrm{C}-$ $\mathrm{Br}$ bond of EBIB in the presence of $\mathrm{Y}(\mathrm{OTf})_{3}$. Thus, the stereocontrolled radical polymerization was initiated by the $\mathrm{C}-\mathrm{Br}$ bond cleavage of EBIB assisted by $\mathrm{Y}(\mathrm{OTf})_{3}$.

Table I. Polymerization of NIPAM under different conditions ${ }^{a}$

\begin{tabular}{|c|c|c|c|c|c|c|c|c|}
\hline Entry & $\begin{array}{c}{[\mathrm{EBIB}]} \\
(\mathrm{mM})\end{array}$ & $\begin{array}{c}{\left[\mathrm{Y}(\mathrm{OTf})_{3}\right]} \\
(\mathrm{M})\end{array}$ & $\begin{array}{l}\text { Temp. } \\
\left({ }^{\circ} \mathrm{C}\right)\end{array}$ & $\begin{array}{l}\text { Time } \\
\text { (h) }\end{array}$ & $\begin{array}{l}\text { Yield } \\
(\%)^{\mathrm{b}}\end{array}$ & $\begin{array}{c}M_{\mathrm{n}} \\
\left(\times 10^{-4}\right)^{\mathrm{c}}\end{array}$ & $M_{\mathrm{w}} / M_{\mathrm{n}}^{\mathrm{c}}$ & $\begin{array}{l}\text { Tacticity } \\
(\mathrm{m} / \mathrm{r})^{\mathrm{d}}\end{array}$ \\
\hline 1 & - & 0.15 & 80 & 13 & 0 & - & - & - \\
\hline 2 & 10 & - & 80 & 17 & 0 & - & - & - \\
\hline 3 & 10 & 0.17 & 60 & 17 & 0 & - & - & - \\
\hline 4 & 10 & 0.17 & 80 & 13 & 75.4 & 8.89 & 2.72 & $79 / 21$ \\
\hline 5 & 10 & 0.17 & 100 & 13 & 88.0 & 7.67 & 2.50 & $77 / 23$ \\
\hline 6 & 10 & - & 30 (UV) & 24 & 76.8 & 9.59 & 2.58 & $43 / 57$ \\
\hline 7 & 10 & 0.20 & 30 (UV) & 24 & 96.3 & 2.68 & 2.86 & $86 / 14$ \\
\hline $8^{e}$ & 10 & 0.14 & 80 & 17 & 0 & - & - & - \\
\hline
\end{tabular}

${ }^{\mathrm{a}}[\mathrm{NIPAM}]_{\mathrm{o}}=1.25 \mathrm{M}$, total volume of the methanol/toluene $(1 / 1, \mathrm{v} / \mathrm{v})$ mixture $=4 \mathrm{~mL}$. ${ }^{\mathrm{b}}$ Ether-insoluble part. ${ }^{\mathrm{c}}$ Determined by SEC (PS standard, $0.1 \mathrm{M} \mathrm{LiCl}$ solution of dimethylformamide at $40{ }^{\circ} \mathrm{C}$ ). ${ }^{\mathrm{d}}$ Determined by ${ }^{1} \mathrm{H}$ NMR in DMSO- $d_{6}$ at $170{ }^{\circ} \mathrm{C}$. ${ }^{\mathrm{e}}$ In the presence of $[\mathrm{DPPH}]_{\mathrm{o}}=20 \mathrm{mM}$. 

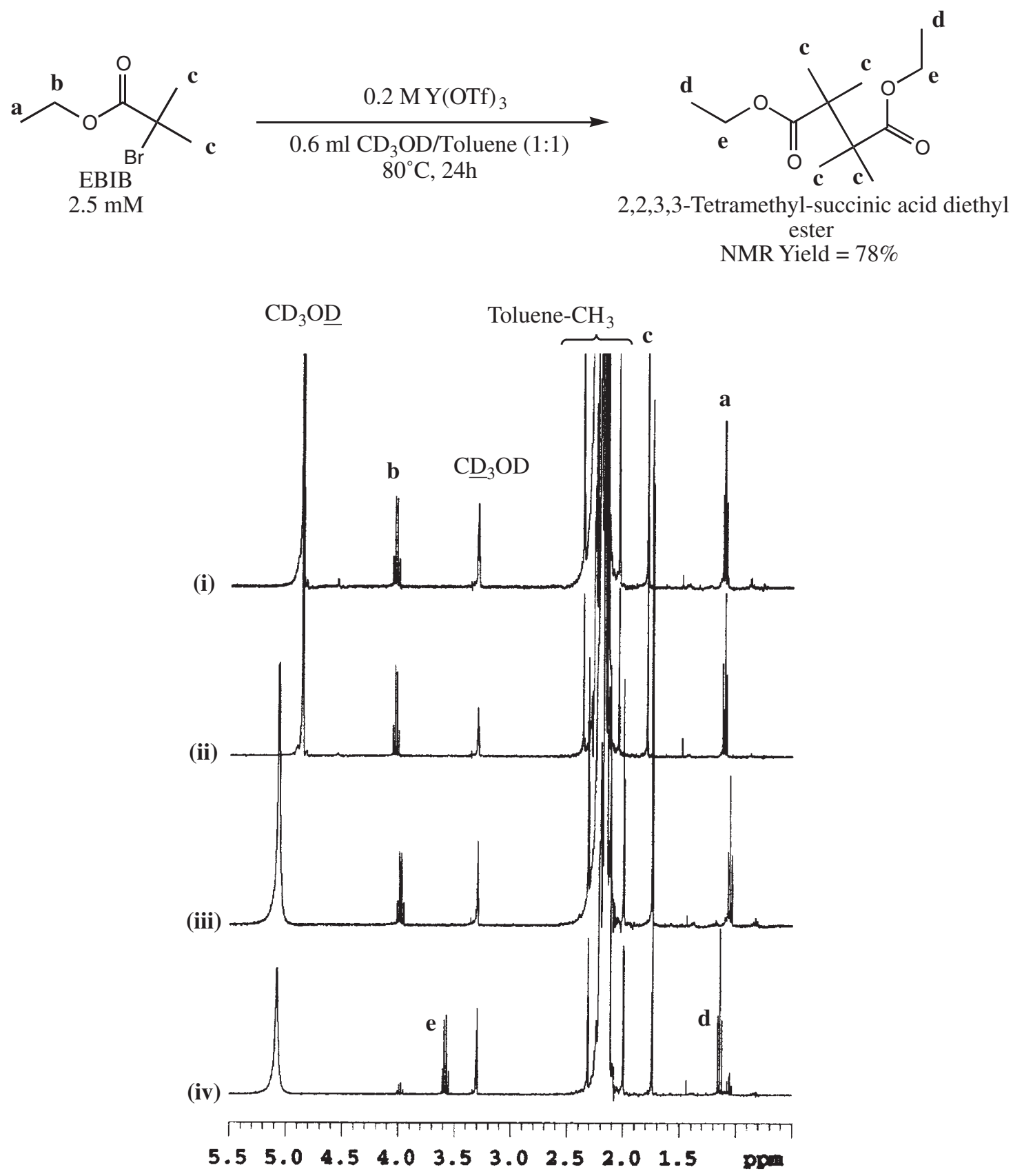

Figure 1. ${ }^{1} \mathrm{H}$ NMR $\left(400 \mathrm{MHz}\right.$, room temperature) spectra of $\mathrm{EBIB}(2.5 \mathrm{mM})$ in $\mathrm{CD}_{3} \mathrm{OD} /$ toluene $(1 / 1, \mathrm{v} / \mathrm{v})$ mixture (i) before and (ii) after heating at $80^{\circ} \mathrm{C}$ for $24 \mathrm{~h} .{ }^{1} \mathrm{H}$ NMR $(400 \mathrm{MHz}$, room temperature $)$ spectra of EBIB $(2.5 \mathrm{mM})$ and $\mathrm{Y}(\mathrm{OTf})_{3}(0.2 \mathrm{M})$ mixture in CD ${ }_{3} \mathrm{OD} /$ toluene $(1 / 1, \mathrm{v} / \mathrm{v})$ mixture (iii) before and (iv) after heating at $80^{\circ} \mathrm{C}$ for $24 \mathrm{~h}$.

\section{Effect of Solvent}

In order to understand the effect of solvents, the NIPAM polymerization was done in different solvents using the $\mathrm{EBIB} / \mathrm{Y}(\mathrm{OTf})_{3}$ initiating system at $80^{\circ} \mathrm{C}$ (Table II). The polymer yield was nearly quantitative in a methanol-toluene $(1 / 1, \mathrm{v} / \mathrm{v})$ mixture (entry 3$)$, but minimal $(29.3 \%)$ in toluene, which may be due to the insolubility of the Lewis acid in toluene. The polymer yields are relatively low in methanol (57\%) (entry 1) and in DMF (46\%) (entry 4). This may be due to the stronger interaction of the Lewis acid with these polar solvents than with EBIB. ${ }^{11}$ In all cases, the observed molecular weights were higher than the theoretical value (14000) assuming that one molecule of EBIB generates one polymer chain. The polydispersity of the polymers is also high (1.87-3.53). The molecular weight control was not attained because of the irreversible formation of the radical species, the slow initiation, and/or bimolecular termination. The tacticity of the obtained polymers decreased in the following order: methanol $>$ methanol-toluene mixture $(1 / 1$, $\mathrm{v} / \mathrm{v})>\mathrm{DMF}>$ toluene. Therefore, $\mathrm{EBIB} / \mathrm{Y}(\mathrm{OTf})_{3}$ produced the poly(NIPAM) with a high isotacticity in a high yield in a methanol-toluene $(1 / 1, \mathrm{v} / \mathrm{v})$ mixture. 
Table II. Effect of solvent type on $\mathrm{Y}(\mathrm{OTf})_{3} / \mathrm{EBIB}$ initiation system for the polymerization of NIPAM ${ }^{\mathrm{a}}$

\begin{tabular}{cccccc}
\hline Entry & Solvent & $\begin{array}{c}\text { Yield } \\
(\%)^{\mathrm{b}}\end{array}$ & $\begin{array}{c}M_{\mathrm{n}} \\
\left(\times 10^{-4}\right)^{\mathrm{c}}\end{array}$ & $M_{\mathrm{w}} / M_{\mathrm{n}}{ }^{\mathrm{c}}$ & $\begin{array}{c}\text { Tacticity } \\
(\mathrm{m} / \mathrm{r})^{\mathrm{d}}\end{array}$ \\
\hline 1 & MeOH & 57 & 8.94 & 2.86 & $81 / 19$ \\
2 & Toluene & 29 & 26.8 & 3.24 & $51 / 49$ \\
3 & MeOH-Tol (1/1) & 96 & 6.67 & 3.53 & $80 / 20$ \\
4 & DMF & 46 & 4.06 & 1.87 & $54 / 46$ \\
\hline
\end{tabular}

${ }^{\mathrm{a}}[\mathrm{NIPAM}]_{\mathrm{o}}=1.25 \mathrm{M},[\mathrm{EBIB}]_{\mathrm{o}}=10 \mathrm{mM},\left[\mathrm{Y}(\mathrm{OTf})_{3}\right]_{\mathrm{o}}=0.2 \mathrm{M}$, total volume of solvent $=4 \mathrm{~mL}$, temp. $=80^{\circ} \mathrm{C}$, time $=13 \mathrm{~h} .{ }^{\text {b }}$ Ether-insoluble part. ${ }^{\mathrm{c}}$ Determined by SEC in DMF containing $0.1 \mathrm{M}$ $\mathrm{LiCl}$ at $40{ }^{\circ} \mathrm{C}$ (PS standard). ${ }^{\mathrm{d}}$ Determined by ${ }^{1} \mathrm{H}$ NMR $(400 \mathrm{MHz})$ in DMSO- $d_{6}$ at $170{ }^{\circ} \mathrm{C}$.

Table III. Effect of variation of the composition of $\mathrm{Y}(\mathrm{OTf})_{3}$ and EBIB on the polymerization of NIPAM ${ }^{\mathrm{a}}$

\begin{tabular}{ccccccc}
\hline Entry & $\begin{array}{c}{[\mathrm{EBIB}]_{\mathrm{o}}} \\
(\mathrm{mM})\end{array}$ & $\begin{array}{c}{\left[\mathrm{Y}(\mathrm{OTf})_{3}\right]_{\mathrm{o}}} \\
(\mathrm{mM})\end{array}$ & $\begin{array}{c}\text { Yield } \\
(\%)^{\mathrm{b}}\end{array}$ & $\begin{array}{c}M_{\mathrm{n}} \\
\left(\times 10^{-4}\right)^{\mathrm{c}}\end{array}$ & $M_{\mathrm{w}} / M_{\mathrm{n}}{ }^{\mathrm{c}}$ & $\begin{array}{c}\text { Tacticity } \\
(\mathrm{m} / \mathrm{r})^{\mathrm{d}}\end{array}$ \\
\hline 1 & 10 & 10 & 12 & 25.6 & 2.58 & $65 / 35$ \\
2 & 10 & 100 & 62 & 19.5 & 2.68 & $78 / 22$ \\
3 & 10 & 170 & 75 & 8.89 & 2.72 & $79 / 21$ \\
4 & 10 & 200 & 96 & 6.67 & 3.53 & $80 / 20$ \\
5 & 20 & 170 & 80 & 7.54 & 2.86 & $79 / 21$ \\
6 & 30 & 170 & 84 & 6.56 & 3.08 & $79 / 21$ \\
\hline
\end{tabular}

${ }^{\mathrm{a}}[\mathrm{NIPAM}]_{\mathrm{o}}=1.25 \mathrm{M}$, total volume of methanol $/$ toluene $(1 / 1, \mathrm{v} / \mathrm{v})$ mixture $=4 \mathrm{~mL}$, temp. $=$ $80^{\circ} \mathrm{C}$, time $=13 \mathrm{~h} .{ }^{\mathrm{b}}$ Ether-insoluble part. ${ }^{\mathrm{c}}$ Determined by SEC in DMF containing $0.1 \mathrm{M} \mathrm{LiCl}$ at $40{ }^{\circ} \mathrm{C}$ (PS standard). ${ }^{\mathrm{d}}$ Determined by ${ }^{1} \mathrm{H}$ NMR $(400 \mathrm{MHz})$ in DMSO- $d_{6}$ at $170{ }^{\circ} \mathrm{C}$.

\section{Effects of Concentrations of $Y(O T f)_{3}$ and EBIB}

The effects of the concentrations of EBIB and $\mathrm{Y}(\mathrm{OTf})_{3}$ on the polymerization of NIPAM in methanol-toluene $(1 / 1, \mathrm{v} / \mathrm{v})$ at $80^{\circ} \mathrm{C}$ are shown in Table III. The increase in the concentration of $\mathrm{Y}(\mathrm{OTf})_{3}$ from $0.01 \mathrm{M}$ to $0.2 \mathrm{M}$ (entries 1-4) keeping the other conditions constant induced the increase in the polymer yield, the decrease in the molecular weight of the polymer, the increase in the polydispersities and the increase in the polymer tacticity. These results indicate that the radical concentration increases at high $\mathrm{Y}(\mathrm{OTf})_{3}$ concentrations. The increase in the isotacticity of the polymer is ascribed to the effective complexation of $\mathrm{Y}(\mathrm{OTf})_{3}$ with the last two pendant amide groups of the propagating radical and the incoming monomer unit which in turn favors the meso-type addition of the Lewis acid-complexed NIPAM monomer. Similar observations have been reported for the polymerization of acrylamides, ${ }^{15,16,18,19,22}$ methacrylamides, ${ }^{16-21}$ and methacrylates $^{24}$ in the presence of bulky lanthanide triflate Lewis acids. The increase in the EBIB concentration from $10 \mathrm{mM}$ to $30 \mathrm{mM}$ (entries 3, 5 and 6) while keeping other conditions the same increases the polymer yield, decreases the molecular weight of the polymer, and increases the polydispersities. These results indicate that the radical concentration increases with an increase in the EBIB concentration, which eventually increases the polymer yield and decreases the ob- served molecular weight as expected. The tacticity of the obtained polymers remained unchanged with an increase in the EBIB concentration.

\section{Kinetics Study}

Figure 2 shows the typical time-conversion curve for the polymerization of NIPAM using the EBIB/ $\mathrm{Y}(\mathrm{OTf})_{3}$ initiation system in a methanol-toluene $(1 / 1, \mathrm{v} / \mathrm{v})$ mixture at $80^{\circ} \mathrm{C}$. The reaction was slow in comparison to that of $\mathrm{AIBN} / \mathrm{Y}(\mathrm{OTf})_{3}{ }^{19}$ and the monomer conversion increased with an increase in the polymerization time. The corresponding conversion vs. number average molecular weight $\left(M_{\mathrm{n}}\right)$ and polydispersity $\left(M_{\mathrm{w}} / M_{\mathrm{n}}\right)$ curves are shown in Figure 3. The molecular weight of the polymers decreased with an increase in the conversion, and the polydispersity increased with the conversion until around 2.8 at $60 \%$ conversion. The plots of the molecular weights $v s$. conversion are quite similar to those with $\mathrm{AIBN} / \mathrm{Y}(\mathrm{OTf})_{3} .{ }^{25}$

\section{Effect of Type of Lewis Acid}

We also studied the polymerization of NIPAM in the presence of EBIB using $\mathrm{Yb}(\mathrm{OTf})_{3}, \mathrm{Lu}(\mathrm{OTf})_{3}$, and $\mathrm{Sc}(\mathrm{OTf})_{3}$ as Lewis acids under the same conditions (Table IV, entries 2, 3, and 4). The polymer yield is relatively lower $(71 \%)$ for $\mathrm{Sc}(\mathrm{OTf})_{3}$ compared to $\mathrm{Y}(\mathrm{OTf})_{3}, \mathrm{Yb}(\mathrm{OTf})_{3}$, and $\mathrm{Lu}(\mathrm{OTf})_{3}$. This may be due to the higher complexation of $\mathrm{Sc}(\mathrm{OTf})_{3}$ with sol- 


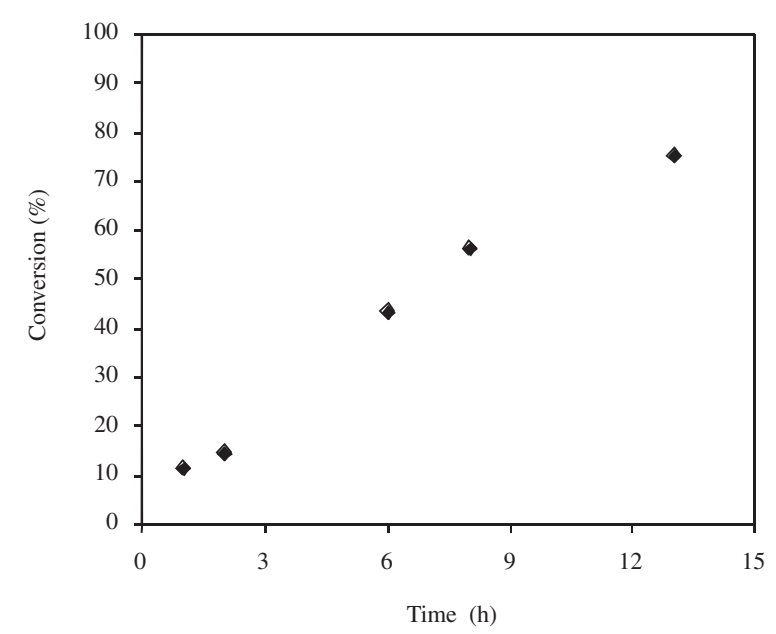

Figure 2. Plot of time vs. conversion (\%) in the polymerization of $N$-isopropylacrylamide (NIPAM) using [NIPAM] $=1.25$ $\mathrm{M},[\mathrm{EBIB}]=10 \mathrm{mM},\left[\mathrm{Y}(\mathrm{OTf})_{3}\right]=0.17 \mathrm{M}$ in methanol/toluene $(1 / 1, v / v)$ mixture at $80^{\circ} \mathrm{C}$.

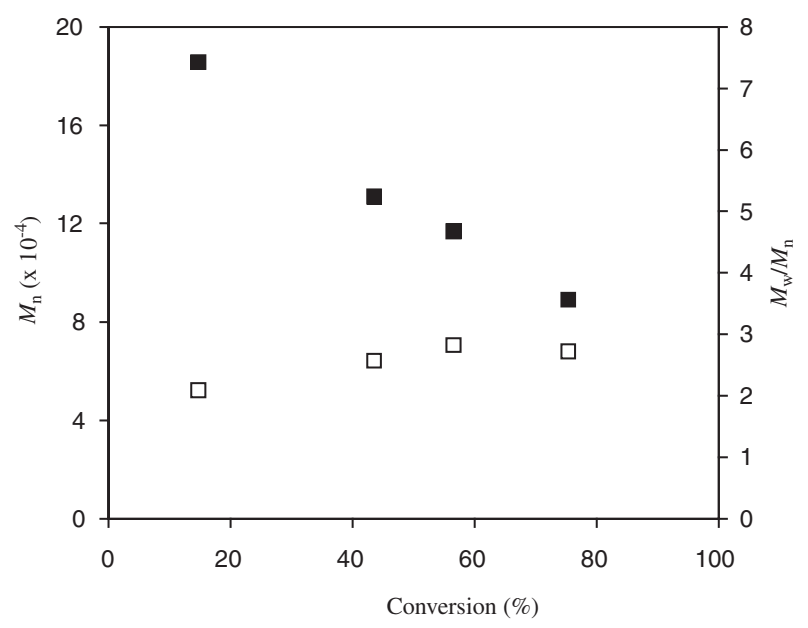

Figure 3. Plots of conversion (\%) vs. number average molecular weight $\left(M_{\mathrm{n}}\right)$ and polydispersity $\left(M_{\mathrm{w}} / M_{\mathrm{n}}\right)$ in the polymerization of $N$-isopropylacrylamide (NIPAM) using [NIPAM] $=1.25$ $\mathrm{M},[\mathrm{EBIB}]=10 \mathrm{mM},\left[\mathrm{Y}(\mathrm{OTf})_{3}\right]=0.17 \mathrm{M}$ in methanol/toluene $(1 / 1, \mathrm{v} / \mathrm{v})$ mixture at $80^{\circ} \mathrm{C}$ : (田 $M_{\mathrm{n}}$ (expt.), ( $\left.\square\right) M_{\mathrm{w}} / M_{\mathrm{n}}$ (expt.).

Table IV. Effect of different rare earth metal triflate Lewis acids on the polymerization of NIPAM ${ }^{\mathrm{a}}$

\begin{tabular}{cccccc}
\hline Entry & $\begin{array}{c}\text { Lewis } \\
\text { acid }\end{array}$ & $\begin{array}{c}\text { Yield } \\
(\%)^{\mathrm{b}}\end{array}$ & $\begin{array}{c}M_{\mathrm{n}} \\
\left(\times 10^{-4}\right)^{\mathrm{c}}\end{array}$ & $M_{\mathrm{w}} / M_{\mathrm{n}}{ }^{\mathrm{c}}$ & $\begin{array}{c}\text { Tacticity } \\
(\mathrm{m} / \mathrm{r})^{\mathrm{d}}\end{array}$ \\
\hline 1 & ${\mathrm{Y}(\mathrm{OTf})_{3}}_{2}$ & 96 & 6.67 & 3.53 & $80 / 20$ \\
2 & $\mathrm{Yb}(\mathrm{OTf})_{3}$ & 77 & 9.59 & 2.35 & $82 / 18$ \\
3 & $\mathrm{Lu}(\mathrm{OTf})_{3}$ & 94 & 5.50 & 3.45 & $80 / 20$ \\
4 & $\mathrm{Sc}(\mathrm{OTf})_{3}$ & 71 & 5.12 & 1.86 & $65 / 35$ \\
\hline
\end{tabular}

${ }^{\mathrm{a}}[\mathrm{NIPAM}]_{\mathrm{o}}=1.25 \mathrm{M} \cdot[\mathrm{EBIB}]_{\mathrm{o}}=10 \mathrm{mM},[\text { Lewis acid }]_{\mathrm{o}}=$ $0.20 \mathrm{M}$, total volume of methanol/toluene $(1 / 1, \mathrm{v} / \mathrm{v})$ mixture $=4 \mathrm{~mL}$. time $=13 \mathrm{~h}$. ${ }^{\mathrm{b}}$ Ether-insoluble part. ${ }^{\mathrm{c}}$ Determined by SEC in DMF containing $0.1 \mathrm{M} \mathrm{LiCl}$ at $40^{\circ} \mathrm{C}$ (PS standard). ${ }^{\mathrm{d}}$ Determined by ${ }^{1} \mathrm{H}$ NMR $(400 \mathrm{MHz})$ in DMSO- $d_{6}$ at $170^{\circ} \mathrm{C}$.

vent (methanol-toluene mixture here) than with the carbonyl group of EBIB. ${ }^{11}$ The observed molecular weights were always higher than the theoretical value. The polydispersities of the polymer increased as the polymer yield increased. In all the cases, the polymers are isotactic rich. $\mathrm{Y}(\mathrm{OTf})_{3}, \mathrm{Yb}(\mathrm{OTf})_{3}$, and $\mathrm{Lu}(\mathrm{OTf})_{3}$ produced the polymers with $m \cong 80 \%$, and $\mathrm{Sc}(\mathrm{OTf})_{3}$ was less effective as reported earlier. ${ }^{15} \mathrm{Sc}$ has the smallest ionic radii, and may be the most acidic. However, its effect on the isotacticity was the lowest. Therefore, the higher coordination number of $\mathrm{Y}(\mathrm{OTf})_{3}, \mathrm{Yb}(\mathrm{OTf})_{3}$, and $\mathrm{Lu}(\mathrm{OTf})_{3}$ due to the presence of $4 \mathrm{f}$ orbitals, which is not present to $\operatorname{Sc}(\mathrm{OTf})_{3}$, may play an important role in the tacticity control.

\section{Effect of Structure of Bromide Initiator}

The effect of the alkyl bromides on the initiation efficiency was studied using ethyl-2-bromopropionate (EBP) and $N, N$-dimethyl-2-bromo-2-methylpropanamide (DBMP) (Scheme 2). In EBP, bromine is connected to a secondary $\alpha$-carbonyl carbon center of the ester, while in DBMP, the bromine is attached to a tertiary $\alpha$-carbonyl carbon of a $N, N$-di-substituted amide group. The results of the polymerization of NIPAM using $\mathrm{EBIB} / \mathrm{Y}(\mathrm{OTf})_{3} \quad$ (entry 1$), \quad \mathrm{EBP} / \mathrm{Y}(\mathrm{OTf})_{3}$ (entry 2) and $\mathrm{DBMP} / \mathrm{Y}(\mathrm{OTf})_{3}$ (entry 3 ) in methanol-toluene $(1 / 1, \mathrm{v} / \mathrm{v})$ mixture at $80^{\circ} \mathrm{C}$ are shown in Table V. Under the same conditions, the polymer yield is maximum (95\%) with the DBMP system followed by EBIB (75\%) and EBP (38\%). The molecular weights are close for DBMP and EBIB, and higher values with EBP. The initiation rate may be decreased in the order DBMP $>$ EBIB $>$ EBP. These results are probably explained by the order of the $\mathrm{C}-\mathrm{Br}$ bond strength (tertiary $\mathrm{C}-\mathrm{Br}<$ secondary $\mathrm{C}-\mathrm{Br}$ ) and the coordination ability of the substituents (amide $>$ ester). Therefore, DBMP is a better initiator than EBIB and EBP.<smiles>CCOC(=O)C(C)Br</smiles>

Ethyl 2-bromopropionate (EBP)<smiles>CN(C)C(=O)C(C)(C)Br</smiles>

$N, N$-Dimethyl-2-bromo-2-methylpropanamide (DBMP)

Scheme 2. Structure of alkyl bromides used in the polymerization. 
Table V. Effect of the structure of alkyl bromide initiator in the polymerization of NIPAM at $80^{\circ} \mathrm{C}$ for $13 \mathrm{~h}^{\mathrm{a}}$

\begin{tabular}{clccc}
\hline Entry & R-Br & $\begin{array}{c}\text { Yield } \\
(\%)^{\mathrm{b}}\end{array}$ & $\begin{array}{c}M_{\mathrm{n}} \\
\left(\times 10^{-4}\right)^{\mathrm{c}}\end{array}$ & $M_{\mathrm{w}} / M_{\mathrm{n}}{ }^{\mathrm{c}}$ \\
\hline 1 & EBIB & 75.4 & 8.89 & 2.72 \\
2 & EBP & 37.2 & 13.34 & 2.40 \\
3 & DBMP & 94.6 & 8.73 & 2.39 \\
\hline
\end{tabular}

${ }^{\mathrm{a}}[\mathrm{NIPAM}]_{\mathrm{o}}=1.25 \mathrm{M}, \quad[\mathrm{R}-\mathrm{Br}]_{\mathrm{o}}=10 \mathrm{mM}, \quad\left[\mathrm{Y}(\mathrm{OTf})_{3}\right]_{\mathrm{o}}=$ $0.17 \mathrm{M}$, total volume of the methanol/toluene $(1 / 1, \mathrm{v} / \mathrm{v})$ mixture $=4 \mathrm{~mL} .{ }^{\mathrm{b}}$ Ether-insoluble part. ${ }^{\mathrm{c}}$ Determined by SEC (PS standard, $0.1 \mathrm{M} \mathrm{LiCl}$ solution of dimethylformamide at $\left.40^{\circ} \mathrm{C}\right)$.

\section{Chain-End Analysis of Polymer}

Figure 4 shows the ${ }^{1} \mathrm{H}$ NMR spectrum $(400 \mathrm{MHz}$, DMSO- $\left.d_{6}, \mathrm{RT}\right)$ of the poly(NIPAM) prepared with $\mathrm{Sc}(\mathrm{OTf})_{3}$ and EBIB in a toluene-methanol (1:1, $\mathrm{v} / \mathrm{v}$ ) mixture at $80^{\circ} \mathrm{C}$. Apart from the characteristic peaks of the methyl (e) and methine (d) protons of the isopropyl group, and backbone methylene (a) and methine (b) protons of the main-chain repeating units of NIPAM, the methylene proton (h) of the ethyl ester group of the initiator EBIB at the $\alpha$-chain-end of the polymer was observed at $4.1 \mathrm{ppm}$. The corresponding methyl protons ( $g$ and i) of the EBIB initiator were overlapped with the methyl protons (e) of the isopropyl group at around $1 \mathrm{ppm}$. The small peak (f) at $5.3 \mathrm{ppm}$ corresponds to the methine proton adjacent to the bromine at the $\omega$-chain-end of the polymer. The amido methine (c) proton of the polymer was observed at around $6.8 \mathrm{ppm}$. Therefore, the EBIB initiator fragment exists at the polymer chain-end. More- over, the $M_{\mathrm{n}}$ of the polymer can be calculated from the peak intensity ratios of the methine (d) proton of the isopropyl group to the methylene proton (h) at the $\alpha$-chain-end of the polymer if each polymer chain possesses one initiator fragment. The $M_{\mathrm{n}}(\mathrm{NMR})$ value is 69,400 which is higher than the $M_{\mathrm{n}}=51,200$ by SEC. This discrepancy may be due to the use of standard polystyrene for the calibration in the GPC measurement. However, some poly(NIPAM) samples did not show the small peak (f) at $5.3 \mathrm{ppm}$ that corresponds to the methine proton adjacent to the bromine at the $\omega$-chain end of the polymer. This may be due to the bimolecular chain termination that took place like the conventional radical polymerization.

Based on all these results, we can conclude that EBIB itself cannot form any radical even upon heating at $80^{\circ} \mathrm{C}$. When the Lewis acids complexed with it at $80^{\circ} \mathrm{C}$, a radical is formed, which in turn, performs the polymerization of the Lewis acid-complexed NIPAM through a meso-type stereocontrol addition (Scheme 3). UV light itself can yield a radical from EBIB alone or from the EBIB-Y(OTf $)_{3}$ mixture even at $30^{\circ} \mathrm{C}$. Therefore, the polymerization proceeds via a radical pathway and the initiation from EBIB is assisted by the Lewis acids. The resulting polymer is isotactic. The chain termination occurred by the combination of the propagating radical with the free bromide radical. However, the possibility of bimolecular chain termination as in a conventional radical polymerization cannot be ruled out.

\section{Polymerization of Different Monomers}

The results of the polymerizations of other mono-
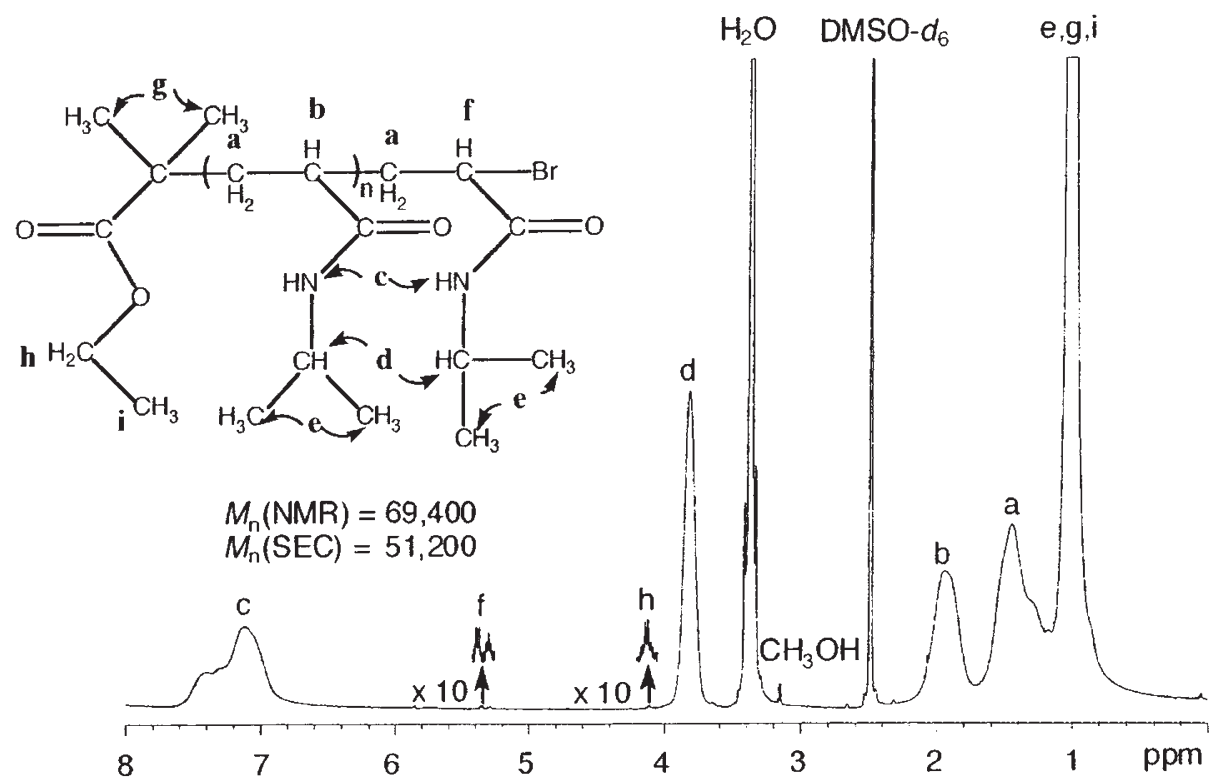

Figure 4. ${ }^{1} \mathrm{H}$ NMR $\left(400 \mathrm{MHz}\right.$, DMSO- $d_{6}$, room temperature $)$ spectrum of isotactic poly(NIPAM) $\left(M_{\mathrm{n}}=51,200, M_{\mathrm{w}} / M_{\mathrm{n}}=1.86\right)$ obtained in the polymerization of NIPAM $(1.25 \mathrm{M})$ using EBIB initiator $(10 \mathrm{mM})$ and $\mathrm{Y}(\mathrm{OTf})_{3}(0.17 \mathrm{M})$ in methanol/toluene $(1 / 1$, v/v) mixture at $80^{\circ} \mathrm{C}$. 
(a) Initiation<smiles>CCOC(=O)C(C)(C)Br</smiles>

(b) Propagation<smiles></smiles>

(c) Termination

$$
\begin{aligned}
& \mathrm{P}_{\mathrm{n}}+\mathrm{Br}^{\cdot} \longrightarrow \mathrm{P}_{\mathrm{n}} \longrightarrow \mathrm{Br} \\
& \mathrm{P}_{\mathrm{n}} \cdot+\mathrm{P}_{\mathrm{m}} \cdot \mathrm{or} \longrightarrow \mathrm{P}_{\mathrm{n}} \longrightarrow \mathrm{P}_{\mathrm{m}} \text { or } \mathrm{P}_{\mathrm{n}} \mathrm{H}+\mathrm{P}_{\mathrm{m}}=
\end{aligned}
$$

Scheme 3. Possible mechanism for polymerization.

Table VI. Results of polymerization of different monomers using $\mathrm{Y}(\mathrm{OTf})_{3} / \mathrm{EBIB}$ initiation system at $80^{\circ} \mathrm{C}^{\mathrm{a}}$

\begin{tabular}{clcccc}
\hline Entry & Monomer & Comonomer & $\begin{array}{c}\text { Yield } \\
(\%)^{\mathrm{b}}\end{array}$ & $\begin{array}{c}M_{\mathrm{n}} \\
\left(\times 10^{-4}\right)^{\mathrm{c}}\end{array}$ & $M_{\mathrm{w}} / M_{\mathrm{n}}{ }^{\mathrm{c}}$ \\
\hline 1 & DMAM & - & 98.3 & 5.09 & 3.48 \\
2 & Styrene & - & 8.5 & 3.65 & 2.70 \\
3 & $n$-Butyl acrylate & - & 16.2 & 5.44 & 1.42 \\
4 & MMA & - & 10.0 & 22.8 & 4.30 \\
$5^{\text {d }}$ & Styrene & NIPAM & 35.2 & 24.2 & 2.10 \\
\hline
\end{tabular}

${ }^{\mathrm{a}}[\text { Monomer }]_{\mathrm{o}}=1.25 \mathrm{M},[\mathrm{EBIB}]_{\mathrm{o}}=10 \mathrm{mM},\left[\mathrm{Y}(\mathrm{OTf})_{3}\right]_{\mathrm{o}}=0.2 \mathrm{M}$, total volume of methanol toluene $(1 / 1, \mathrm{v} / \mathrm{v})$ mixture $=4 \mathrm{~mL}$, temperature $=80^{\circ} \mathrm{C}$, time $=13 \mathrm{~h}$. ${ }^{\mathrm{b}}$ Ether-insoluble part. ${ }^{\mathrm{c}}$ Determined by SEC (PS standard): entry 1,5: in DMF containing $0.1 \mathrm{M} \mathrm{LiCl}$ at $40^{\circ} \mathrm{C}$; entries 2-4: in $\mathrm{THF}$ at $40^{\circ} \mathrm{C}$. ${ }^{\mathrm{d}}[\mathrm{Monomer}]_{\mathrm{o}}=[\mathrm{Co}-$ monomer $]_{\mathrm{o}}=0.625 \mathrm{M}$.

mers using the $\mathrm{EBIB} / \mathrm{Y}(\mathrm{OTf})_{3}$ initiation system in the methanol-toluene $(1 / 1, \mathrm{v} / \mathrm{v})$ mixture at $80^{\circ} \mathrm{C}$ are shown in Table VI. DMAM was quantitatively polymerized (entry 1). The tacticty of the obtained polymer is $m=82 \% .{ }^{26}$ The polymer yields for styrene, $n$-butylacrylate, and MMA are lower (entries 2, 3 and 4). This may be due to the lower solubility of $\mathrm{Y}(\mathrm{OTf})_{3}$ in the polymerization mixture. The obtained poly(MMA) had the triad content of $\mathrm{mm} / \mathrm{mr} / \mathrm{rr}=$ $2 / 33.6 / 64.4$. This tacticity is close to the value for the typical radically-obtained poly(MMA) in the absence of a Lewis acid. ${ }^{24}$ The copolymerization of NIPAM with styrene was successfully done (entry 5). The polymer yield was around $35 \%$. The composition of styrene and NIPAM in the coplymer is $33 \%$ and $67 \%$, respectively.

\section{CONCLUSIONS}

The mixtures of rare earth metal triflate $\left[\mathrm{Y}(\mathrm{OTf})_{3}\right.$, $\left.\mathrm{Yb}(\mathrm{OTf})_{3}, \mathrm{Lu}(\mathrm{OTf})_{3}, \mathrm{Sc}(\mathrm{OTf})_{3}\right]$ Lewis acid and alkyl halide containing $\alpha$-esters [ethyl 2-bromoisobutyrate (EBIB) and ethyl 2-bromopropionate] or $\alpha$-amide ( $N, N$-dimethyl-2-bromo-2-methylpropanamide) were used as a novel thermal latent radical initiating system at $80^{\circ} \mathrm{C}$ for the stereocontrolled radical polymerization of $\mathrm{N}$-isopropylacrylamide. Here, the Lewis acids serve the dual role as a promoter for initiation and a controller for the stereochemistry of the polymerization process. The effect of DPPH and the formation of the EBIB dimer confirmed the radical nature of the polymerization. $\mathrm{Y}(\mathrm{OTf})_{3}$ and $\mathrm{Lu}(\mathrm{OTf})_{3}$ were found to be effective Lewis acids. The increases in the Lewis 
acid and alkyl halide initiator concentrations increased the polymer yield but decreased the molecular weight. The chain-end structure determined by ${ }^{1} \mathrm{H}$ NMR confirmed that the alkyl halide acts as an initiator. The polymerizations of $\mathrm{N}, \mathrm{N}$-dimethylacrylamide, styrene, $n$-butyl acrylate, and methyl methacrylate were also performed using this new initiation system.

Acknowledgment. This work was partly supported by the New Energy and Industrial Technology Development Organization (NEDO) under the Ministry of Economy, Trade and Industry, Japan, through a grant for the "Nanostructure Polymer Project" in the project "Nanotechnology Materials Program" (20012003). B. R. thanks the Venture Business Laboratory (VBL), Nagoya University for providing the Fellowship and also the Japan Society for the Promotion of Science (JSPS) for providing the Fellowship and Research Grant for this work.

\section{REFERENCES}

1. G. Moad and D. H. Solomon, "The Chemistry of Free Radical Polymerization,” Pergamon, Oxford, U.K., 1995.

2. (a) K. Matyjaszewski, Ed., "Controlled Radical Polymerization," ACS Symposium Series 685, American Chemical Society, Washington, D.C., 1998.

(b) K. Matyjaszewski, Ed., "Controlled/Living Radical Polymerization. Progress in ATRP, NMP, and RAFT," ACS Symposium Series 768, American Chemical Society, Washington, D.C., 2000.

3. (a) M. Kamigaito, T. Ando, and M. Sawamoto, Chem. Rev., 101, 3689 (2001).

(b) K. Matyjaszewski and J. Xia, Chem. Rev., 101, 2921 (2001).

4. (a) D. H. Solomon, E. Rizzardo, and P. Cacioli, US Patent 4,581,429, 1986.

(b) M. K. Georges, R. P. N. Veregin, K. M. Kazmaier, and G. K. Hamer, Macromolecules, 26, 2987 (1993).

5. (a) J. Chiefari, Y. K. Chong, F. Ercole, J. Krstina, J. Jeffery, T. P. T. Le, R. T. A. Mayadunne, G. F. Meijs, C. L. Moad, G. Moad, E. Rizzardo, and S. H. Thang, Macromolecules, 31, 5559 (1998).

(b) A. Goto, K. Sato, Y. Tsujii, T. Fukuda, G. Moad, E. Rizzardo, and S. H. Thang, Macromolecules, 34, 402 (2001).

6. (a) D. P. Curran, in "Comprehensive Organic Synthesis," B.
M. Trost and I. Fleming, Ed., Pergamon, Oxford, U.K., 1991, Vol. 4, p 715.

(b) J. Iqbal, B. Bhatia, and N. K. Nayar, Chem. Rev., 94, 519 (1994).

7. Y. Guindon, C. Yoakim, R. Lemieux, L. Boisvert, D. Delorme, and J.-F. Lavallee, Tetrahedron Lett., 31, 2845 (1990).

8. M. P. Sibi and J. Ji, J. Org. Chem., 61, 6090 (1996).

9. Y. Yamamoto, S. Onuki, M. Yumoto, and N. Asao, J. Am. Chem. Soc., 116, 421 (1994).

10. P. Renaud and M. Gerster, Angew. Chem., Int. Ed. Engl., 38, 2661 (1998).

11. C. L. Mero and N. A. Porter, J. Am. Chem. Soc., 121, 5155 (1999).

12. H. Feng, I. K. Kavrakova, D. A. Pratt, J. Tellinghuisen, and N. A. Porter, J. Org. Chem., 67, 6050 (2002).

13. D. A. Pratt, J. S. Wright, and K. U. Ingold, J. Am. Chem. Soc., 121, 489 (1999).

14. K. B. Clark and D. D. M. Wayner, J. Am. Chem. Soc., 113, 9363 (1991).

15. Y. Isobe, D. Fujioka, S. Habaue, and Y. Okamoto, J. Am. Chem. Soc., 123, 7180 (2001).

16. Y. Okamoto, S. Habaue, Y. Isobe, and T. Nakano, Macromol. Symp., 183, 83 (2002).

17. Y. Suito, Y. Isobe, S. Habaue, and Y. Okamoto, J. Polym. Sci., Part A: Polym. Chem., 40, 2496 (2002).

18. S. Habaue, Y. Isobe, and Y. Okamoto, Tetrahedron, 58, 8205 (2002).

19. Y. Okamoto, S. Habaue, and Y. Isobe, in "Advances in Controlled/Living Radical Polymerization,” K. Matyjaszewski, Ed., ACS Symposium Series 854, American Chemical Society, Washington, D.C., 2003, p 59.

20. Y. Isobe, Y. Suito, S. Habaue, and Y. Okamoto, J. Polym. Sci., Part A: Polym. Chem., 41, 1027 (2003).

21. K. Morioka, Y. Suito, Y. Isobe, S. Habaue, and Y. Okamoto, J. Polym. Sci., Part A: Polym. Chem., 41, 3354 (2003).

22. B. Ray, Y. Isobe, K. Morioka, S. Habaue, Y. Okamoto, M. Kamigaito, and M. Sawamoto, Macromolecules, 36, 543 (2003).

23. M. Senoo, Y. Kotani, M. Kamigaito, and M. Sawamoto, Macromolecules, 32, 8005 (1999).

24. Y. Isobe, T. Nakano, and Y. Okamoto, J. Polym. Sci., Part A: Polym. Chem., 39, 1463 (2001).

25. Y. Isobe, Ph. D. Thesis, Nagoya University, Nagoya, 2003.

26. The tacticity $(m \%)$ of the poly(DMAM) obtained using $\mathrm{RuCl}_{2}\left(\mathrm{PPh}_{3}\right)_{3}-\mathrm{EBIB}$ radical polymerization system in the absence of Lewis acid in methanol-toluene $(1 / 1, \mathrm{v} / \mathrm{v})$ mixture at $80^{\circ} \mathrm{C}$ is 50 . 